\title{
PERFORMANCE OF SWEET POTATO VARIETIES IN HILLY AREA
}

\author{
M. Shaheenuzzamn, R. R. Saha, A. Biswas and M. S. Islam \\ Bangladesh Agricultural Research Institute \\ Corresponding author: shaheenuzzamn@gmail.com
}

Key words: Sweet potato varieties, hilly areas, $\beta$-carotene

\begin{abstract}
The experiment was conducted at the research field of Hill Tract Agricultural Research Station. Ramgarh, Khagrachari during Rabi season of 2012-2013 and 2013-14. Five different sweet potato varieties (BARI Sweetpotato-6, BARI Sweetpotato-7, BARI Sweetpotato-8, BARI Swwetpotato-9 and local cultivar were included as treatment variables in the experiment. BARI Sweetpotato-7 had significantly more number of vines (8.30) as compared to local cultivar and other new varieties such as BARI Sweetpotato-6, BARI Sweetpotato-8 and BARI Sweetpotato-9. Maximum number of tuber plant ${ }^{-1}$ (5.4 and 5.3), tuber length $(15.30$ and $15.80 \mathrm{~cm})$, tuber diameter $(5.10$ and $5.20 \mathrm{~cm})$, individual tuber weight (368.35 and $377.69 \mathrm{~g}$ ) and tuber yield (19.89 and $20.13 \mathrm{t} \mathrm{ha}^{-1}$ ) was recorded from BARI Sweetpotato-9 during 2012-13 and 2013-14, respectively whereas local cultivar gave minimum values. The variety BARI Sweetpotato-9 out yielded local cultivar by 108.93 and $103.13 \%$ during two consecutive years but highest net income $(3,10,818$ and 3, 15,617 Tk. ha-1) from BARI Sweetpotato-7.
\end{abstract}

\section{Introduction}

Sweet potato (Ipomea batatas L.) is a cheap source of calories (Adam, 2005) belonging to the family Convolvulaceae, order Polemoniales (Burden, 2005) and is ranked third most important tuber crops after potato (Solanum tuberosum) and cassava (Manihot esculentum) (FAO, 2003). Orange flesh sweet potatoes are rich in $\beta$-carotene. The crop can adapt to a wide range of environmental conditions and grow on marginal areas with poor soils of limited fertility and inadequate moisture (BNC, 2004) with low inputs. It plays a vital role in the daily diet poor men food in Bangladesh. The average yield of sweet potato in Bangladesh is only 9.27 tons per hectare (BBS, 2001), compared to the average world yield of 14.9 tons per hectare (FAO, 2001). The area and total production of sweet potato in Bangladesh are decreasing day by day due to lack of good varieties, relatively long crop duration, post-harvest losses, increasing irrigation facilities turned the growers to grow other cash crops (rice, wheat, potato, maize etc.) Plant characters and yield of sweet potato varied widely among the varieties (Yadav et al., 1996; Anonymous, 1992). The Bangladesh Agricultural Research Institute (BARI) has recently developed several new varieties of sweet potato with yield potential of 25-30 t/ha, but these varieties are not yet available for farmers of the Chattagong Hill Tracts. The total area of Chattagong Hill Tracts is estimated around 13,237 ha which is about 10\% of total land area of the country. After harvest of T.aman there is wide scope to grow high yielding sweet potato varieties because farmers of this area cultivate local cultivars of sweet potato which is poor yielder. Thus, high yielding sweet potato can supplement as a good source of food for mainly marginal farmer of hilly region. With this view, the present study was conducted to find out the performance of recently developed high yielding varieties of sweet potato in the hilly region. 
Shaheenuzzamn et al.

\section{Materials and Methods}

The experiment was conducted at research field of Hill Tract Agricultural Research Station. Ramgarh, Khagrachari during Rabi season of 2012-13 and 2013-14. The soil of this hill area belongs to AEZ 29 and acidic in nature. Five different sweet potato varieties (BARI Sweetpotato6, BARI Sweetpotato-7, BARI Sweetpotato-8, BARI Sweetpotato-9 and local cultivar) were included as treatment variables. The trial was laid out in a randomized complete block design with four replications. Vine of sweet potatoes $30 \mathrm{~cm}$ long cuttings with 3 - 4 nodes were planted on 16 November, 2012 and 20 November, 2013 maintaining spacing of $60 \mathrm{~cm} \times 30 \mathrm{~cm}$. Fertilizers at the rate of $160-150-180 \mathrm{~kg} \mathrm{ha}^{-1}$ of N P K in the form of urea, triple super phosphate (TSP) and muriate of potash (MoP), respectively along with cowdung 10 ton/ha and lime 3 ton/ha. The full amount of lime, cowdung, TSP, MoP, and 1/2 Urea were applied as basal during final land preparation. The remaining of urea and $\mathrm{MoP}$ was side dressed at 60 days after planting (DAP). Irrigation, weeding, earthingup and insecticides were applied as when required It was harvested after 150 DAP when the vines were turned to dry as brown color. Different varietal characteristics and yield contributing characters were recorded. The collected data were analyzed statistically and means were separated using LSD test at 5\% level of significance.

\section{Results and Discussion}

Average number of vine, length of the vines/plant and weight of above-ground biomass/plant during 2012-13 and 2013-14 were shown in Table 1. All the varieties were showed identical number of vines. However, BARI Sweetpotato-7 was more number of vines (8.30) which was at par to BARI Sweetpotato-9 as compared to local cultivar. Variation in branching might be due to the varietal characteristics. The results of the experiment are in agreement with the findings of Hossain (1995). The variety BARI Sweetpotato-7 was recorded the highest length of vine $(291.40 \mathrm{~cm}$ ). The other modern varieties (BARI Sweetpotato-6, BARI Sweetpotato-8, BARI Sweetpotato-9) had second highest length of vines ranged between 240 and $244.67 \mathrm{~cm}$ while local cultivar gave the lowest length of vine $(170.50 \mathrm{~cm})$. The highest weight of above-ground biomass/plant was found from BARI Sweetpotato-7 (0.95 kg plant $\left.{ }^{-1}\right)$ which was at par with that of BARI Sweetpotato-9 $\left(0.85 \mathrm{~kg} \mathrm{plant}^{-1}\right)$ and lowest from local cultivar $\left(0.65 \mathrm{~kg} \mathrm{plant}^{-1}\right)$.

Table 1. Average number of vine plant ${ }^{-1}$, length of the vines and weight of above-ground biomass plant ${ }^{-1}$ of modern varieties and local cultivar of sweet potato was grown in hilly region in two seasons

\begin{tabular}{l|c|c|c}
\hline Varieties & $\begin{array}{c}\text { No. of vines } \\
\text { plant }^{-1}\end{array}$ & Length $(\mathrm{cm})$ of vine & $\begin{array}{c}\text { Wt. (kg) of above-ground } \\
\text { biomass plant }\end{array}$ \\
\hline BARI Sweetpotato-6 & 6.55 & 242.4 & 0.80 \\
BARI Sweetpotato-7 & 8.30 & 291.40 & 0.95 \\
BARI Sweetpotato-8 & 7.30 & 244.67 & 0.80 \\
BARI Sweetpotato-9 & 8.00 & 240.00 & 0.85 \\
local cultivar & 6.00 & 170.50 & 0.65 \\
\hline LSD $_{(0.05)}$ & 0.03 & 3.54 & 0.10 \\
CV $(\%)$ & 2.26 & 7.71 & 6.42 \\
\hline
\end{tabular}

Plant population, yield and yield contributing characters of sweet potato varieties were presented in the Table-2 \& 3. Numerically the maximum number of tuber/plant (5.4 and 5.3)were recorded from BARI Sweetpotato-9 during 2012-13 and 2013-14, respectively while lowest 
Performance of Sweet Potato in Hilly Area

number of tuber/plant was recorded from local cultivar (Table 2). Farooque and Husain (1973) also reported that the number of tubers/ plant varied from 4.70 to 11.76 while Siddique (1985) found from 1.73 to 6.03 .

Table 2. Number of plants $\mathrm{m}^{-2}$, tuber plant ${ }^{-1}$, individual tuber wt. and length of individual tuber of modern varieties and local cultivar of sweet potato was grown in hilly region in two season

\begin{tabular}{l|c|c|c|c|c|c|c}
\hline Treat & \multirow{2}{*}{$\begin{array}{c}\text { No. of } \\
\text { plants } \\
\mathrm{m}^{-2}\end{array}$} & \multicolumn{2}{c|}{ No. of tuber plant-1 } & \multicolumn{2}{c|}{$\begin{array}{c}\text { Individual tuber wt. } \\
(\mathrm{g})\end{array}$} & \multicolumn{2}{c}{$\begin{array}{c}\text { Length of individual } \\
\text { tuber }(\mathrm{cm})\end{array}$} \\
\cline { 3 - 8 } & $2012-13$ & $2013-14$ & $2012-13$ & $2013-14$ & $2012-13$ & $2013-14$ \\
\hline BARI Sweetpotato-6 & 4.5 & 4.7 & 5.0 & 272.85 & 297.27 & 12.50 & 13.50 \\
BARI Sweetpotato-7 & 4.5 & 5.3 & 5.2 & 300.61 & 329.38 & 14.50 & 14.50 \\
BARI Sweetpotato-8 & 4.4 & 3.7 & 4.2 & 308.5 & 318.11 & 13.40 & 14.60 \\
BARI Sweetpotato-9 & 4.3 & 5.4 & 5.3 & 368.35 & 377.69 & 15.30 & 15.80 \\
Local Cultivar & 4.0 & 3.8 & 3.8 & 250.5 & 260.78 & 11.50 & 12.50 \\
\hline LSD $_{(0.05)}$ & $\mathrm{NS}$ & $\mathrm{NS}$ & $\mathrm{NS}$ & 1.29 & 1.59 & 0.90 & 0.87 \\
CV (\%) & 3.72 & 5.46 & 5.78 & 4.31 & 5.45 & 5.58 & 7.78 \\
\hline
\end{tabular}

Individual tuber weight (368.35 g and $377.67 \mathrm{~g})$, length of individual tuber (11.50 and 12.50 $\mathrm{cm})$, diameter of individual tuber $(3.50 \mathrm{~cm}$ and $4.00 \mathrm{~cm})$ and dry matter content of individual tuber (26.09 and $27.00 \%)$ were maximum with BARI Sweetpotato-9 during 2012-13 and 2013-14, respectively. Local variety had lower values in all these parameters; tuber weight $(250.5 \mathrm{~g}$ and $260.78 \mathrm{~g})$, length of tuber $(15.30$ and $15.80 \mathrm{~cm})$, diameter of tuber $(5.10 \mathrm{~cm}$ and $5.20 \mathrm{~cm})$ and dry matter content of tuber $(33.30$ and $34.00 \%)$ for, respectively. The results of the present study were in agreement with the report of Vasconcellos et al. (1986). The other modern varieties; BARI Sweetpotato-7, BARI Sweetpotato-8 and BARI Sweetpotato-6 were superior than local one. The variety BARI Sweetpotato-9 showed the maximum tuber yield (19.89 $\mathrm{t} \mathrm{ha}^{-1}$ and $\left.20.13 \mathrm{t} \mathrm{ha}^{-1}\right)$ followed by BARI Sweetpotato-7 (15.93 and $\left.17.13 \mathrm{t} \mathrm{ha}^{-1}\right)$ in both the years (Table 3). Local cultivar showed the lowest yield (9.52 $\mathrm{t} \mathrm{ha}^{-1}$ and $\left.9.91 \mathrm{t} \mathrm{ha}^{-1}\right)$. The yield increased over local one was 108.93 and $103.13 \%$.

Table 3. Diameter of individual tuber, dry matter content of individual tuber, yield of tuber of modern varieties and local cultivar of sweet potato and yield increase over local cultivar tested in hilly region in two seasons

\begin{tabular}{|c|c|c|c|c|c|c|c|c|}
\hline \multirow[t]{2}{*}{ Treatment } & \multicolumn{2}{|c|}{$\begin{array}{l}\text { Diameter of } \\
\text { tuber }(\mathrm{cm})\end{array}$} & \multicolumn{2}{|c|}{$\begin{array}{c}\text { Dry matter } \\
\text { content tuber }{ }^{-1} \\
\text { (\%) }\end{array}$} & \multicolumn{2}{|c|}{$\begin{array}{l}\text { Tuber yield } \\
\left(\mathrm{t} \mathrm{ha}^{-1}\right)\end{array}$} & \multicolumn{2}{|c|}{$\begin{array}{l}\text { Yield increase } \\
\text { over local } \\
(\%)\end{array}$} \\
\hline & $\begin{array}{c}2012- \\
13\end{array}$ & $\begin{array}{c}2013- \\
14\end{array}$ & $\begin{array}{c}2012- \\
13\end{array}$ & $\begin{array}{c}2013- \\
14\end{array}$ & $\begin{array}{c}2012- \\
13\end{array}$ & $\begin{array}{c}2013- \\
14\end{array}$ & $\begin{array}{c}2012- \\
13\end{array}$ & $\begin{array}{c}2013- \\
14\end{array}$ \\
\hline BARI Sweetpotato-6 & 4.38 & 4.40 & 30.50 & 31.25 & 12.69 & 14.80 & 33.29 & 49.39 \\
\hline BARI Sweetpotato-7 & 4.40 & 4.50 & 31.25 & 32.00 & 15.93 & 17.13 & 67.33 & 72.84 \\
\hline BARI Sweetpotato- 8 & 4.50 & 4.70 & 31.00 & 31.50 & 11.41 & 13.36 & 19.91 & 34.82 \\
\hline BARI Sweetpotato-9 & 5.10 & 5.20 & 33.30 & 34.00 & 19.89 & 20.13 & 108.93 & 103.13 \\
\hline Local Cultivar & 3.50 & 4.00 & 26.09 & 27.00 & 9.52 & 9.91 & - & - \\
\hline $\operatorname{LSD}_{(0.05)}$ & 0.16 & 0.25 & 1.17 & 1.25 & 0.05 & 0.10 & - & - \\
\hline $\mathrm{CV}(\%)$ & 2.05 & 2.50 & 2.00 & 2.75 & 0.00 & 1.75 & - & - \\
\hline
\end{tabular}

The other tested varieties had 33.29 - 72.84\% more yield over local one. These results were similar to the findings of Jahan and Siddique (2001), Siddique et al. (1988), Basuca et al. 
Shaheenuzzamn et al.

(1990), Anonymous (1992), Hossain and Mondal (1994) and Bahera and Jha (1995). It is noted that the potential yield of these potato varieties is $40-45 \mathrm{t} \mathrm{ha}^{-1}$ but all the varieties produced lower tuber yield in the hilly region. It might be due to prevailing lower temperature during November to February when average temperature was below $24^{\circ} \mathrm{C}$ in both the growing season. Sweet potato grows best where average temperature is $24^{0} \mathrm{c}$ (Kay, 1973).

The highest gross and net income from BARISweetpotato-9 was highest (Tk. 310818 ha $^{-1}$ and Tk. $315617 \mathrm{ha}^{-1}$ ) during 2012-13 and 13-14, respectively but other modern variety did not perform will but higher return than local cultivar (Tk. 1,03,380 ha-1 and Tk. 1,11,192 ha-1) (Table 4).

Table 4. Estimated net income of modern varieties and local cultivar of sweet potato was cultivated in hilly region in two seasons

\begin{tabular}{|c|c|c|c|c|c|c|}
\hline \multirow[t]{2}{*}{ Treatments } & \multicolumn{2}{|c|}{ Tuber yield $\left(\mathrm{t} \mathrm{ha}{ }^{-1}\right)$} & \multicolumn{2}{|c|}{ Gross Income (Tk. ha $\left.{ }^{-1}\right)$} & \multicolumn{2}{|c|}{ Net Income (Tk. ha $\left.{ }^{-1}\right)$} \\
\hline & $2012-13$ & 2013-14 & $2012-13$ & 2013-14 & $2012-13$ & 2013-14 \\
\hline BARI Sweetpotato-6 & 12.69 & 14.80 & 253750 & 296080 & 166750 & 209080 \\
\hline BARI Sweetpotato-7 & 15.93 & 17.13 & 318653 & 342555 & 231653 & 255555 \\
\hline BARI Sweetpotato-8 & 11.41 & 13.36 & 228290 & 267212 & 141290 & 180212 \\
\hline BARI Sweetpotato-9 & 19.89 & 20.13 & 397818 & 402617 & 310818 & 315617 \\
\hline Local Cultivar & 9.52 & 9.91 & 190380 & 198192.8 & 103380 & 111192 \\
\hline
\end{tabular}

\section{Conclusion}

The results of the present study indicated that BARI Sweetpotato-9 and BARI Sweetpotato-7 would be suitable sweet potato varieties for cultivation in hilly region of Bangladesh.

\section{References}

Adam K. L., 2005. Sweet potato: organic production. Online. Available from: http:// www.ncat.org/attra-pub/sweet potato.html.

Anonymous. 1992. Annual Report of the Tuber Crops Research Centre, 1991-92.Bangladesh Agricultural Research Institute, Joydebpur, Gazipur. pp.210-246.

Basuca, M. B., E. O. Badol, Z. J. Bascas and L. L. Tandang. 1990. Preliminary Yield Trial on Sweet Potato. Northern Philippines Root Crops Research and Training Centre (NPRCRTC). Research results presented in a series of working papers, BSU-NPRCRTC. 1990. pp.53-62.

BBS (Bangladesh Bureau of Statistics). 2001. Year Book of Agricultural Statistics of Bangladesh. Bangladesh Bureau of Statistics. Statistics Division, Ministry of Planning, Govt. of the People's Republic of Bangladesh, Dhaka.p.105.

Behera, U. K. and K. P. Jha. 1995. On-farm evaluation of promising sweet potato (Ipomoea batatas) varieties for the rainfed unbunded uplands of Kalahandi, Orissa, India. Current Agril. Res., 8 (supplement): 37-38.

BNC (Bioethics Nuffield Council). 2004. The Use of GM Crops in Developing Countries. Case study 5: Improved resistance to viruses in sweet potato.

Burden D. 2005. Sweet Potato Profile, Agricultural Marketing and Resource Centre (AgMRC) A National Information Resource for Value added Agriculture. Iowa State University Publishers. 
Performance of Sweet Potato in Hilly Area

FAO (Food and Agriculture Organization). 2003. Food and Agriculture Organization of the United Nations. Bull. Stat. 4: 46-47 FAO Secretariat Rome, Italy.

FAO (Food and Agriculture Organization). 2001. FAO Production Year Book. Basic Data Unit, Statistics Division, FAO, Rome, Italy, 53: 95.

Farooque A. M. and A. Husain. 1973. Studies on the comparative morphological characters and the yield of the seven varieties of sweet potato. Bangladesh Hort. 1(2): 37-44.

Hossain M. M. and M. A. A. Mondal. 1994. Effect of vine parts on the growth and yield of three sweet potato varieties. Bangladesh J. Sci. Ind. Res. 29(3): 181-184.

Hossain, M. D. 1995. Study on growth, yield, consumer's preference and storage of 30 sweet potato (Ipomoea batatas Lam.) genotypes. M.S. thesis, Department of Horticulture, Bangladesh Agricultural University, Mymensingh. p.49.

Jahan, M. A. and M. A. R. Siddique. 2001. Studies on growth, yield and storage of sweet potato as influenced by variety and time of harvest. M. S. Thesis, Dept. of Horticulture, Bangladesh Agricultural University, Mymensingh. pp.1-84.

Kay D. E. 1973. Crop and product digest 2: Root crops, Tropical product Institute. London, p.245.

Siddique M. A., A. T. M. Hasanuzzaman and A. Husain. 1988. Growth and yield of three high yielding sweet potato genotypes. Bangladesh J. Agric. 13(3): 139-145.

Siddique, M. A. R. 1985. Studies on the morphology, growth and yield of some sweet potato genotypes. M. Sc. (Agriculture) thesis, Dept. of Horticulture, Bangladesh Agricultural University, Mymensingh.

Vasconcellos H. D, D. L. Almeida, N. R. Leal and M. Braga Neto. 1986. Comparison of sweet potato (I.pomoea batatas L.) cultivars in the municipality of vassouras-RJ. Comunicado Tecnico, Empresa de Pesquia Agropecuaria do estado do Rio de Janeiro. 163: 3.

Yadav G. R., U. Sing and T. R. Dayal. 1996. Performance of sweet potato cultivar under North Indian condition. Recent Hort. 3(1): 98. 